\title{
TO STUDY THE EFFECT OF THE PARENTERAL ADMINISTRATION OF CIMETIDINE ON SERUM PROLACTIN LEVEL IN EXPERIMENTAL ANIMALS
}

\author{
Oinam Joychandra Singh ${ }^{1}$, S. Losica R. K
}

${ }^{1}$ Associate Professor, Department of Pharmacology, JNIMS, Imphal, Manipur.

2Postgraduate Student, Department of Pharmacology, JNIMS, Imphal, Manipur.

\begin{abstract}
BACKGROUND
ABSTRACT

Among the $\mathrm{H} 2$ receptor antagonists, Cimetidine promotes healing of peptic ulcer and reduces ulcer pain, but produces a few significant side effects- gynaecomastia, galactorrhoea, etc. H1 antagonists and H2 agonists suppress prolactin release in suckled mother, while $\mathrm{H} 1$ agonists and $\mathrm{H} 2$ antagonists release prolactin in non-suckled mother. ${ }^{2}$ The relationship between $\mathrm{H} 2$ receptor inhibitory and $\mathrm{H} 1$ receptor stimulant for the raise or decrease of serum prolactin level and also for involvement of third ventricle in hypothalamus area is to be investigated.
\end{abstract}

\section{MATERIALS AND METHODS}

The present study was to ascertain the site of action of Cimetidine for the raised serum prolactin, whether peripheral action or central action. Therefore, the route of administration of the $\mathrm{H} 2$ receptor antagonist Cimetidine was chosen as intravenous and intracerebroventricular respectively. Finally, serum prolactin level was estimated by drawing blood from the ear vein of the experimental animal (Rabbit) every $15 \mathrm{mins}, 30 \mathrm{mins}$ and $45 \mathrm{mins}$ respectively. Then, serum prolactin levels were compared and analysed statistically.

\section{RESULTS}

The serum prolactin level was found significantly raised at 15 mins $(\mathrm{p}<0.05)$ and 30 mins $(\mathrm{p}<0.001)$ after the IV Cimetidine. However, there is no significant difference between IV Cimetidine and ICV Cimetidine pre-treated group as Diphenhydramine blocked $\mathrm{H} 1$ receptor.

\section{CONCLUSION}

So, it can be concluded that Cimetidine causes raise in serum prolactin level due to its peripheral and central action.

\section{KEYWORDS}

Prolactin, Cimetidine, Diphenhydramine, Intracerebroventricular, Radioimmunoassay, Rabbits.

HOW TO CITE THIS ARTICLE: Singh OJ, Losica SRK. To study the effect of the parenteral administration of cimetidine on serum prolactin level in experimental animals. J. Evolution Med. Dent. Sci. 2018;7(13):1599-1601, DOI: 10.14260/jemds/2018/362

\section{BACKGROUND}

The involvement of histamine in controlling of gastric acid secretion was supported with the discovery of specific inhibitor of $\mathrm{H} 2$ receptor on parietal cells. The role of histamine and its pharmacological importance has increasingly come to light after which the characterisation of $\mathrm{H} 2$ receptor antagonists- Burimamide, Metiamide and Cimetidine. ${ }^{1}$ Among the $\mathrm{H} 2$ receptor antagonists, Cimetidine promotes healing of peptic ulcer and reduces ulcer pain, but produces a few significant side effects- gynaecomastia, galactorrhoea, etc. $\mathrm{H} 1$ antagonists and $\mathrm{H} 2$ agonists suppress prolactin release in suckled mother, while $\mathrm{H} 1$ agonists and $\mathrm{H} 2$ antagonists release prolactin in non-suckled mother. ${ }^{2}$ The relationship between $\mathrm{H} 2$ receptor inhibitory and $\mathrm{H} 1$ receptor stimulant for the raise or decrease of serum prolactin level and also for involvement of third ventricle in hypothalamus area is to be investigated. ${ }^{3}$

'Financial or Other Competing Interest': None.

Submission 19-01-2018, Peer Review 12-03-2018,

Acceptance 18-03-2018, Published 26-03-2018.

Corresponding Author:

Dr. S. Losica R. K,

Quarter No.5, Phase II,

Transit Quarter, Sanjenthong,

Imphal-795001,

Manipur.

E-mail: lul.amethystlu.rk@gmail.com

DOI: $10.14260 /$ jemds $/ 2018 / 362$
There is a report that the parenteral administration of Cimetidine produces many changes in hormone profile. 4,5 The rise in prolactin secretion after IV Cimetidine is widely agreed, but the mechanism of action is still unclear. ${ }^{6}$ Even though there were many reports of raised prolactin level with many side effects, ${ }^{7}$ only a few case of raised prolactin level is related with Cimetidine administration. ${ }^{8}$ But the effect of the newer $\mathrm{H} 2$ receptor antagonists Ranitidine does not produce the rise in serum prolactin level even after IV Ranitidine. ${ }^{9}$

\section{MATERIALS AND METHODS}

This randomised, controlled study was conducted in the Postgraduate Department of Pharmacology, the Nuclear Medicine and RIA unit of the Postgraduate Department of Medicine and Therapeutics, SN Medical College, Agra as part of dissertation of Postgraduate study.

\section{Grouping of Animals}

Twenty-four adult albino rabbits (1 - $2 \mathrm{~kg}$ ) of either sex were fed on chana and green vegetables for two weeks before starting the study. The animals were randomly grouped (six rabbits in each group).

a. IV Cimetidine group.

b. IV Cimetidine pre-treated with Diphenhydramine group (DH).

c. ICV Cimetidine group.

d. ICV Cimetidine pre-treated with Diphenhydramine group. 


\section{Selected Time for Collection of Sample}

Pre-drug blood samples for estimation of prolactin level were collected between 11 am to $1 \mathrm{pm}$ as the stabilisation of prolactin level for several hours is recorded after $10 \mathrm{am} .{ }^{10}$

\section{Chemical Used}

a. Cimetidine (Pharma, Research Dept., Glaxo Group).

b. Diphenhydramine HCL.

c. Reagents and radioactive materials for radioimmunoassay of prolactin (Dr. AF Parlow, Los Angeles, USA).

d. Sodium Azide $0.1 \%$ solution.

\section{Collection and Storage of Samples}

$5 \mathrm{~mL}$ of blood samples were collected from each animal with clean and dry syringes taking all precautions to avoid haemolysis. The samples were transferred to a clean dry test tube of $8 \mathrm{~mL}$. After $10 \mathrm{mins}$, the serum was separated and transferred to the clean vials (approx. $2.5 \mathrm{~mL}$ serum). 1-2 drops of $0.1 \%$ sodium azide solution was added to the serum and the resultant sample were stored at $2^{\circ} \mathrm{C}$ deep freezer.

\section{Implantation of Intracerebroventricular (ICV) Cannula} ICV cannulas were implanted to twelve rabbits (Group $\mathrm{C}$ and D) under Urethane anaesthesia $(0.5-1 \mathrm{gm} / \mathrm{kg}) .{ }^{11}$

\section{Administration of Cimetidine \\ Group A (Intravenous Cimetidine Treated Group)}

Six rabbits were injected Cimetidine $50 \mathrm{mg} / \mathrm{kg}$ intravenously. ${ }^{12}$ Samples of blood were collected at 15 mins, 30 mins and 45 mins respectively from ear vein as the raised prolactin level was repeatedly observed after 10 - 45 minutes of IV Cimetidine therapy.

\section{Group B (IV Cimetidine and Diphenhydramine Treated Group)}

Six rabbits were pre-treated intravenously with Diphenhydramine HCL at a dose of $7.5 \mathrm{mg} / \mathrm{kg} .{ }^{13}$ After one hour, the same rabbits were again injected Cimetidine $(50$ $\mathrm{mg} / \mathrm{kg}$ ) intravenously. ${ }^{12}$ Samples of blood were drawn at 15 mins, 30 mins and 45 mins respectively as done in Group A.

\section{Group C (ICV Cimetidine Treated Group)}

Six rabbits were administered Cimetidine $(50 \mathrm{mg} / \mathrm{kg}$ ) through ICV cannulas after withdrawing the same amount of ventricular fluid. ${ }^{14}$ Blood samples were collected at 15 mins, 30 mins and 45 mins after the infusion of Cimetidine as done in Group A.

\section{Group D (ICV Cimetidine and Diphenhydramine Treated Group)}

Six rabbits were pre-treated with Diphenhydramine HCL (7.5 $\mathrm{mg} / \mathrm{kg}$ ) through the ICV cannula, after withdrawal the same amount of ventricular fluid ${ }^{15}$ prior to the ICV infusion of Cimetidine. After one hour, Cimetidine $(50 \mathrm{mg} / \mathrm{kg})$ was infused through the ICV cannula as in case of Group C. ${ }^{14}$ Then blood samples were collected at 15 mins, 30 mins and 45 mins as done in Group A.

\section{RIA of Prolactin}

The estimation of serum prolactin level was done by using the protocol of WHO Radioimmunoassay ( $3^{\text {rd }}$ edition January
1981). ${ }^{16}$ The level of prolactin was measured by using the EGL ZRS-23 Scintillation Gamma Counter. The observations of the Prolactin levels were expressed as $\mathrm{mI} \mu / \mathrm{L}$.

\section{Statistical Analysis}

The data were expressed as Mean \pm SD. Comparison between two means was carried out by one-way analysis of variance (ANOVA) supplemented with Dunnett's ' $t$ ' test by using SPSS software version 10, where $\mathrm{p}<0.05$ was considered significant.

\section{RESULTS}

The serum prolactin levels in normal rabbits treated with IV Cimetidine (Group A) was 1873.16 $\pm 543.04,2147.33 \pm 393.77$ and $1550.5 \pm 398.59$ at 15,30 and 45 mins respectively. The rise in prolactin level was maximum at 30 mins and was statistically significant $(\mathrm{p}<0.01)$ when compared with the prolactin level of the own control $(1165.33 \pm 95.3)$.

The serum prolactin level in pre-treated rabbits treated with IV Cimetidine (Group B) were $1231.16 \pm 628.31$, $1399.66 \pm 484.77$ and $1117.16 \pm 158.49$ at 15,30 and 45 mins respectively. The level of the prolactin is slightly increased when compared with the own control $1040 \pm 135.36$, but not significant.

The serum prolactin level in normal rabbits treated with ICV Cimetidine (Group C) were 1446.50 \pm 274.48, $1449.30 \pm 583.82$ and $984.5 \pm 78.09$ at 15,30 and 45 mins respectively. There was raise in prolactin level at 15 and 30 mins when compared with own control $1204.16 \pm 247.48$, but the raised level was not significant.

The serum prolactin level in pre-treated rabbits treated with ICV Cimetidine (Group D was 1200.16 \pm 231.12, $1570.5 \pm 746.46$ and $1183 \pm 348.83$ at 15,30 and 45 mins respectively. There is considerable raise of prolactin level at

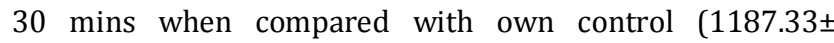
296.78), but this raise in prolactin level is insignificant.

\begin{tabular}{|c|c|c|c|c|}
\hline & \multicolumn{4}{|c|}{ Time Interval in Minutes } \\
\hline \multirow{2}{*}{ Group } & $\begin{array}{c}\text { 0 (Before } \\
\text { any Drug) }\end{array}$ & $\mathbf{1 5}$ mins & $\mathbf{3 0}$ mins & $\mathbf{4 5}$ mins \\
\hline IV Cimetidine & $\begin{array}{c}1165.33 \pm \\
95.3\end{array}$ & $\begin{array}{c}1873.16 \pm \\
543.04^{*}\end{array}$ & $2147.33 \pm$ & $1550.5 \pm$ \\
& $1040 \pm$ & $1231.16 \pm$ & $1399.66 \pm$ & $1117.16 \pm$ \\
IV Cimetidine & 135.36 & 628.31 & 484.77 & $158.49 \mathrm{~b}$ \\
+ DP & $1204.16 \pm$ & $1446.5 \pm$ & $1449.33 \pm$ & $984.5 \pm$ \\
\hline ICV Cimetidine & 247.48 & 274.48 & 583.82 & $78.09 \mathrm{~b}$ \\
\hline ICV Cimetidine & $1187.33 \pm$ & $1200.16 \pm$ & $1570.5 \pm$ & $1183 \pm$ \\
+ DP & 296.78 & 231.12 & 746.46 & $348.83^{\mathrm{b}}$ \\
\hline Table 1. Mean Serum Prolactin Level (mIU/L) of Control \\
Intravenous, Intracerebroventricular Therapies of \\
Cimetidine
\end{tabular}

*DP- Diphenhydramine.

Each value is expressed as mean \pm SD of six observations. ${ }^{*} \mathrm{p}<0.05,{ }^{* *} \mathrm{p}<0.01$ when compared with corresponding values of its control group.

Within a column means marked with different superscript letters are significantly different $(* p<0.05)$ as analysed by Tukey-Kramer multiple comparisons test. 


\section{DISCUSSION}

Measurement of serum prolactin level was done with the method of RIA. ${ }^{15}$ The technique is very sensitive, precision, specificity and accuracy. ${ }^{17}$ Daily and Diurnal variation in prolactin level could not document as only single blood sample was collected between $10 \mathrm{am}-1 \mathrm{pm}$ as stabilisation of prolactin level for several hours occurs after $10 \mathrm{am} .{ }^{11}$

The estimated serum prolactin level in normal rabbits ranged from $650 \mathrm{mI} \mu / \mathrm{L}$ to $2142 \mathrm{mI} \mu / \mathrm{L}$ and the mean level was respectively $1356.03 \pm 532.09 \mathrm{mI} \mu / \mathrm{L}$.

The serum prolactin levels estimated in rabbits after parenteral therapy of cimetidine were significantly raised on 30 mins (IV). These findings supported the observations of Bateson et al, ${ }^{18}$ Burland et al, ${ }^{4}$ Carlson et al, ${ }^{19}$ Winter et al,20 Penden et $\mathrm{al}^{21}$ and Nelis et al. ${ }^{6}$ The prolactin levels in pretreated rabbits were found insignificantly raised on statistical analysis (Diagram).

The observation may show a clue for finding the mechanism of action of Hyperprolactin due to IV Cimetidine administration, i.e. peripheral and central action as Cimetidine crosses the Blood Brain Barrier (Asseis et al,22 Majumdar et al,23 Speigel et al, ${ }^{24}$ Schentag et $\mathrm{al}^{25}$ ) and that of ICV Cimetidine was only to central action. Lastly, Cimetidine produces Hyperprolactinaemia whether IV or ICV, but the hyperprolactinaemia through ICV is less significant because the role of $\mathrm{H} 1$ receptor which is blocked by DP is involved.

\section{CONCLUSION}

The study was an effort for finding the mechanism of Hyperprolactinaemia with the synthetic $\mathrm{H} 2$ receptor antagonist Cimetidine during the parenteral administration. The present observations may support the action of Cimetidine, which can cross Blood Brain Barrier for producing hyperprolactinaemia through peripheral and central actions.

\section{ACKNOWLEDGEMENT}

The authors are grateful to Dr. DK Hazra, Reader of Nuclear Medicine and RIA unit of the Postgraduate Department of Medicine, Dr. RB Verma, Reader, Clinical Pharmacologist for allowing the conduct of the experiment in the PG Lab of Clinical Pharmacology, Department of Pharmacology and also allowing the estimation of prolactin level in the Nuclear Medicine and RIA unit.

\section{REFERENCES}

[1] Brimblecombe RW, Duncan WA, Durant GJ, et al. Characterization and development of Cimetidine as a histamine H2-receptor antagonists. Gastroentrology 1978;74(2 Pt 2):339-47.

[2] Beaven MA. Histamine. New Eng J Med 1979;204:30-6.

[3] Arakelian MC, Libertun C. H1 and H2 receptor participation in brain control of prolactin secretion in lactating rats. Endocrinology 1977;100(3):890-5.

[4] Burland WL, Duncan WA, Hessalbo T, et al. Pharmacological evaluation of Cimetidine, a new histamine H2-receptor antagonist, in healthy man. Brit J Clin Pharm 1975;2(6):481-6.

[5] Carlson HE, Drenick EJ, Chopra IJ, et al. Alteration in basal and TRH stimulated serum level of Thyrotropin, Prolactin and Thyroid hormone in starved obese men. J Clin End Metab 1977;45(4):707-13.
[6] Nelis GF, van de Meene JG. Comparative effect of Cimetidine and Ranitidine on prolactin secretion. Postgrad Med J 1980;56(657):470-80.

[7] Torre DL, Falorni A. Pharmacological causes of Hyperprolactin. Ther Clin Risk Manag 2007;3(5):92951.

[8] Singh OJ, Singh TI, Valte V, et al. Comparison of serum prolactin level between I.V. Ranitidine and I.V. Cimetidine administration in Albino Rabbits and possible role of histamine $\mathrm{H} 1$ and $\mathrm{H} 2$ receptors in prolactin secretion. Indian Medical Gazette 2013;14-7.

[9] Singh OJ, Singh TI, Valte V. Cimetidine induced Hyperprolactinemia. Journal of Medical Society 2013;27(3):165-8.

[10] Finkelstein JW, Kapen S, Weitzman ED, et al. Twentyfour-hour plasma prolactin patterns in prepubertal and adolescent boys. J Clin Endocrinol Metab 1978;47(5):1123-8.

[11] Feldberg W, Sherwood SL. Injection of drugs into the lateral ventricle of the cat. The J Physiol 1954;123(1):148-167.

[12] Okebe JS. Effect of Histamine H2 antagonist Cimetidine, Ranitidine on Aspirin induced gastric lesion in rats and dogs. Gastrogent 1980;5(2):1242.

[13] Carruthers SG, Shoemann DW, Hignite CE, et al. Correlation between plasma Diphenhydramine level and sedation and anti-histaminic effect. Clin Pharm Ther 1978;23(4):375-82.

[14] Reynold LR, Rubel AM, Nikitovich-Winer MB. Cimetidine inhabits the histamine-induced prolactin released in male rats. Pros Soc Exp Biol Med 1980;163(3):332.

[15] Bhargava JK, Tandri J. The Central vasoactive effect of 5HT. Brit J Pharma 1959;14:411.

[16] Sanlat BS. Prolactin radioimmunoassay. WHO protocol 1981:5.

[17] Hazra DK. Radio Immuno Assay and related procedure in medicine. International Atomic Energy Agency, Vienna 1977.

[18] Bateson MC, Browning MC, Maconnachie A. Galactorrhoea with cimetidine. Lancet 1977;310(8031):247-8.

[19] Carlson HE, Drenick EJ. Cimetidine H2 antagonist stimulantion prolactin secretion in man. J Clin End Metab 1979;45:367-70.

[20] Winter AJC, Weston PC, MacDonald JC. The H2 antagonist cimetidine is an anti-androgens in rats. Gastroentrology 1979;76:504-8.

[21] Penden NR, Cargill JM, Browning MC, et al. Male sexual dysfunction during treatment with cimetidine. Brit Med J 1979;1(6164):659.

[22] Asseis J, Schellekers APM, Touber JL. Prolactin in human CSF. J Clin Endo Metab 1978;46(4):576-86.

[23] Majumdar SK. Cimetidine and serum prolactin. Brit J Med 1978;1(6117):921.

[24] Speigel AM, Lopatin R, Peikin S, et al. Serum prolactin in patients receiving chronic oral cimetidine. Lancet 1978;1:881.

[25] Schentag JJ, Cerra FB, Calleri G, et al. Pharmacokinetic and clinical studies in patients with cimetidine associated mental confusion. Lancet 1979;313(8109):177-81. 